University of Wollongong

Research Online

Faculty of Social Sciences - Papers (Archive) Faculty of Arts, Social Sciences \& Humanities

29-1-2018

Two studies of the empirical basis of two learning resource-oriented motivational strategies for gifted educators

Anamaria Vladut

University of Erlangen-Nuremberg

Wilma Vialle

University of Wollongong, wvialle@uow.edu.au

Albert Ziegler

University of Erlangen-Nuremberg, albert.ziegler@ewf.uni-erlangen.de

Follow this and additional works at: https://ro.uow.edu.au/sspapers

Part of the Education Commons, and the Social and Behavioral Sciences Commons

Research Online is the open access institutional repository for the University of Wollongong. For further information contact the UOW Library: research-pubs@uow.edu.au 


\title{
Two studies of the empirical basis of two learning resource-oriented motivational strategies for gifted educators
}

\author{
Abstract \\ Two learning resource-oriented motivational strategies for gifted educators are introduced: a homeostatic \\ orientation that aims for balance and an allostatic orientation that aims at growth. In order to establish \\ the empirical basis of these motivational strategies, two studies were conducted with samples of \\ students from a specialized post-secondary business school who were enrolled in grades 11-13. Study 1 \\ focused on the empirical basis of the homeostatic orientation. It was shown that the availability of \\ learning resources is associated with two forms of balance within an actiotope: robustness and \\ resilience. Furthermore, it could be shown that the effects of exogenous learning resources on \\ robustness and resilience are mediated by endogenous learning resources. The focus of Study 2 was the \\ empirical basis of the allostatic orientation. It was shown that the availability of learning resources is \\ associated with various indicators of growth of an actiotope. Similarly to Study 1 , the effects of \\ exogenous learning resources on outcome variables representing the growth of an actiotope were \\ mediated by endogenous learning resources. Thus, evidence suggests that a homeostatic orientation as \\ well as an allostatic orientation are valid motivational strategies for gifted educators.
}

\section{Keywords}

learning, resource-oriented, studies, educators, motivational, empirical, basis, two, gifted, strategies

\section{Disciplines}

Education | Social and Behavioral Sciences

\section{Publication Details}

Vladut, A., Vialle, W. \& Ziegler, A. (2016). Two studies of the empirical basis of two learning resourceoriented motivational strategies for gifted educators. High Ability Studiesst, 27 (1), 39-60. 
Two Studies of the Empirical Basis of Two Learning Resource-Oriented Motivational Strategies for Gifted Educators

\author{
Anamaria Vladut $^{1}$, Wilma Vialle ${ }^{2} \&$ Albert $_{\text {Ziegler }}{ }^{1}$ \\ ${ }^{1}$ University of Erlangen-Nuremberg, Germany \\ ${ }^{2}$ University of Wollongong, Australia
}

Correspondence Address:

Anamaria Vladut, Dipl.-Psych.

Department of Educational Psychology and Research on Excellence

University of Erlangen-Nuremberg

Dutzendteichstr. 24,

90478 Nuremberg, Germany

Email: anamaria.vladut@,fau.de 


\begin{abstract}
Two learning resource-oriented motivational strategies for gifted educators are introduced: a homeostatic orientation that aims for balance and an allostatic orientation that aims at growth. In order to establish the empirical basis of these motivational strategies, two studies were conducted with samples of students from a specialized post-secondary business school who were enrolled in grades 11 to 13. Study 1 focused on the empirical basis of the homeostatic orientation. It was shown that the availability of learning resources is associated with two forms of balance within an actiotope: robustness and resilience. Furthermore, it could be shown that the effects of exogenous learning resources on robustness and resilience are mediated by endogenous learning resources. The focus of Study 2 was the empirical basis of the allostatic orientation. It was shown that the availability of learning resources is associated with various indicators of growth of an actiotope. Similarly to Study 1, the effects of exogenous learning resources on outcome variables representing the growth of an actiotope were mediated by endogenous learning resources. Thus, evidence suggests that a homeostatic orientation as well as an allostatic orientation are valid motivational strategies for gifted educators.
\end{abstract}

Keywords: actiotope, educational capital, learning capital, resilience, robustness, motivation 
Motivation is a complex and multi-faceted topic in gifted education. Educational efforts need to:

(1) target multiple stakeholders (e.g., the gifted individual, peers, parents, teachers, mentors; Csikszentmihalyi, Rathunde, \& Whalen, 1993; Grassinger, Porath, \& Ziegler, 2010; Siegle \& McCoach, 2005);

(2) motivate for a multitude of possible different goals even when they are reduced to a manageable number (Ford, 1992; Schunk, Pintrich, \& Meece, 2008);

(3) consider many different causes and processes mediating motivated behaviour, such as intrinsic motivation, curiosity, and attributions (Gottfried \& Gottfried, 2009; Gottfried, Gottfried, \& Guerin, 2006).

This raises the question whether it is possible to develop generic motivational strategies for gifted education or whether gifted educators need to follow the more arduous route of devising motivational strategies to fit each single desired action for which gifted individuals might need educational support.

No formal definition exists of the term, motivational strategy, nor of its two constituents, motivation and strategy. The term strategy usually refers to a high level plan to achieve a class of goals while the term motivation usually refers to the causes underlying people's choices as well as the intensity and direction of their behaviour. Drawing on the semantic bases of these two concepts, we use the following definition for our topic: A gifted educator's motivational strategy is their systematic preference for the behaviours that will presumably lead to desired outcomes among gifted individuals.

This definition deliberately leaves open the delineation of which outcomes are desired as this is ultimately up to the gifted educators themselves. Nevertheless, we would argue that the gifted educator should expect behaviours among gifted individuals that are underpinned by research. Ziegler, Chandler, Vialle, and Stoeger (in press) suggested two outcomes, which they thought pivotal for gifted education: a learning resource-oriented homeostatic orientation that aims for balance; and a learning resource-oriented allostatic orientation that aims at growth. However, until now there has only been scattered empirical evidence to corroborate the important role the authors subscribed to these orientations. This is the objective of the current work. However, before we introduce the two motivational strategies in detail, we need to address some conceptual issues pertaining to learning resource orientation.

\section{Two Types of Learning Resources and their Regulation}

Resources are the means to attain a goal. Learning resources, in turn, are the resources required to attain learning goals. Two types of resources can be distinguished depending on where they are located in the actiotope of an individual - an actiotope is defined as comprising an individual and the material, social, and informational environment with which the individual interacts (Ziegler, Vialle, \& Wimmer, 2013). Exogenous resources, also termed educational capital by Ziegler and Baker (2013), are located in the environmental component of the actiotope. Endogenous resources, also termed learning capital by Ziegler and Baker (2013), are located in the individual component of the actiotope. Five different types of educational capital and five different types of learning capital have been proposed (Ziegler \& Baker, 2013). Table 1 provides their definitions along with illustrative examples.

\section{Insert Table 1 around here}

It is important to note that educational and learning capital are relational constructs, which means that an actiotope can be rich with regard to a specific learning goal, but poor in regard to another learning goal. For example, if parents value mathematics but not music, the actiotope of their child might be rich in cultural educational capital for the goal of successful 
learning in mathematics, but poor in cultural educational capital for the goal of successful learning in music.

People are in a constant exchange of matter, energy, and information with their environment (Ziegler \& Baker, 2013). This exchange is vital for keeping their internal conditions stable and keeping them functioning within a normal range. The technical term for this type of regulation is homeostasis (from the Greek 'homo' for 'similar' and 'stasis' for 'standing still'). Examples of important homeostatic processes are sleep regulation, thermoregulation, and stress regulation. There are also many familiar occasions when gifted individuals have to exert homeostatic regulation, such as the underachievement that arises from boredom, twice exceptionality, or the negative consequences of being labelled as gifted (Shavinina, 2009). These phenomena share the common feature that they threaten the balance within gifted individuals.

Despite the fact that humans try to keep their system in a normal state in many respects, they obviously do not stay the same. In particular, gifted individuals, by definition, have a high potential for growth and thus change (Ziegler et al., 2013). In order to be able to change, a continuous influx of resources into the actiotope is necessary and, consequently, a different type of regulation has to be exerted. The objective is then not to maintain homeostasis and remain the same, but rather to challenge homeostasis and re-establish it at a different (skill) level. The main challenge, then, is to co-evolve the learning resources as well as the whole actiotope (see Ziegler \& Phillipson, 2012).

\section{Two Learning Resource-Oriented Motivational Strategies}

Ziegler, Chandler et al. (in press) distinguish two learning resource-oriented motivational strategies for gifted educators, which they termed a homeostatic orientation and an allostatic orientation. A homeostatic orientation is characterized by the motivation to use learning resources to keep the actiotope of a gifted individual in balance. There are two ways to attain this, robustness and resilience. Kitano (2004) defines robustness as "a property that allows a system to maintain its function despite external and internal perturbations" (p. 826). By contrast, resilience requires adaptation (Allen \& Holling, 2008; Gunderson, Folke, \& Jansen, 2006). An illustrative example is a tree during a storm; a strong trunk delivers robustness, but the tree can also adapt and bend and thereby show resilience.

In contrast, an allostatic orientation is characterized by the motivation to utilize learning resources that increase the action repertoire of an actiotope and thereby make it more effective. Thus, it aims at development, learning, and growth.

Figure 1 depicts these basic theoretical assumptions. The basic unit of analysis is the actiotope of a gifted individual. Its boundary is permeable in both directions, that is, it is in a continuous exchange of energy, matter, and resources with its environment. Of particular importance is the influx of educational capital, which will be processed into learning capital and, consequently enable either homeostatic balance or allostatic growth of the actiotope.

\section{Insert Figure 1 around here}

Previous research supported these basic theoretical assumptions in three respects. First, with respect to a homeostatic orientation there is evidence that the possession of exogenous and endogenous learning resources is associated with indicators of robustness and resilience such as self-confidence, failure coping and stability-related beliefs (e.g., Vladut, Vialle, \& Ziegler, 2015; Vladut, Liu, Leana-Tascilar, Vialle, \& Ziegler, 2015; Leana-Tascilar, 2015). Second, with respect to an allostatic orientation there is evidence that the possession of exogenous and endogenous learning resources is associated with variables that represent growth of an actiotope in a domain (e.g., Vladut et al., 2015; Ziegler, Debatin, \& Stoeger, submitted). For 
example, in three studies Ziegler, Debatin, and Stoeger (submitted) found consistent evidence that the availability and higher usage of educational and learning capital is associated with higher skill levels. This finding held for three different domains (school achievements, STEM careers, long-distance running) with various achievement indicators (school marks, professional success, running times) and heterogeneous samples (fifth grade school students, adult long-distance runners, women's retrospective assessments of their educational and learning capital as university students and thus considerably before their professional success). Furthermore, the authors found that educational and learning capital added incremental validity beyond a classical IQ test. Finally, Veas, Castejóna, O’Reilly, and Ziegler (submitted) found that the effect of educational capital on achievement is mediated by learning capital.

\section{The current research}

In this work we propose two general motivational strategies for gifted educators: a learning resource-oriented homeostatic orientation; and a learning resource-oriented allostatic orientation. Through two studies we investigate their empirical basis underpinned by two assumptions. First it has to be shown that possession of educational and learning capital are associated with homeostatic balance and allostatic development. Indeed, there is some preliminary evidence for this claim but we will use more distinct indicators in the studies. Second, the hypothesis that the effect of educational capital on indicators of homeostatic balance and allostatic growth is mediated by learning capital has only been demonstrated for achievement as an outcome variable. In Study 1 we focus on homeostatic balance and in Study 2 on allostatic development.

\section{Study 1}

The first aim of Study 1 was to determine whether the possession of learning resources supports homeostatic balance within an actiotope. To this end various indicators of robustness and resilience were measured along with the possession of educational and learning capital. The second aim was to explore whether the effect of educational capital on robustness and resilience is mediated by learning capital.

We consider two indicators of the robustness of an actiotope-self-confidence and stability beliefs - and two indicators of the resilience of an actiotope - modifiability beliefs and the ability to cope with failure. We analyse these variables with regard to scholastic learning.

A high level of self-confidence indicates that a person is robust across a great range of situations and exhibits their usual behaviour. As long as the self-confidence does not reflect overconfidence, higher levels are associated with better learning processes, higher achievement and more adaptive behavior (e.g. Dweck, 1999; Gist \& Mitchell, 1992; Pajares, 1996). Ziegler, Fidelman, Reutlinger, Vialle, and Stoeger (2010) proposed the need to distinguish between two beliefs about one's own learning. A stability belief refers to the conviction that one's learning reliably leads to success across a wide variety of situations and, thus, the result of one's learning is stable. Therefore, like self-confidence, this belief is an indicator of the robustness of a person across situations.

Ziegler et al. (2010) also postulated a belief similar to Dweck's incremental view (e.g. 1999, 2006). Dweck assumes that individuals either perceive their abilities and intelligence as stable (entity theory) or they perceive them as malleable (incremental theory). In contrast to Dweck's approach, Ziegler et al. (2010) limited the belief to the modifiability of one's own deficits. In other words, this belief is an indicator how much a person believes in their own resilience. However, while belief in one's own resilience might be important for the initiation of adaptive behavior, it should not be confused with resilient behavior as such. Thus, we were also interested in an individual's capacity in 'failure coping', that is, not giving up after 
failure, but reacting in a productive way to regain control and initiate new action to attain the desired goal (Mantzicopoulos, 1990; Mietzel, 2005; Newton \& Kenan, 1985).

\section{Method}

\section{Participants}

Our sample consisted of 209 students, 88 male and 121 female, aged from 15 to 19 ( $M=17.17$, $S D=1.02$ ) who attended a specialized post-secondary business school. They were enrolled in grades 11 to 13 . However, as grade level and sex were not systematically related to any of the outcome variables, we pooled the data.

\section{Materials and procedure}

All 209 participants responded to the same materials. First, they were requested to provide some personal data such as gender, age, level of education attained, and school achievement. Then they completed the Questionnaire of Educational and Learning Capital (QELC; Vladut et al., 2013). Finally, they were requested to complete two scales on robustness (selfconfidence, stability beliefs) and two scales on resilience (modifiability beliefs, failure coping). Reliabilities (Cronbach's $\alpha$ ) of the QELC subscales and of the external measures are presented in Table 2. They are all in the acceptable range.

QELC: The QELC consists of ten subscales, five of which measure educational capital and five of which measure learning capital. Each of the ten subscales measures one of the ten forms of educational and learning capital and comprises five items answered on a six-point Likert-type scale, ranging from 1 'I disagree completely' to 6 'I agree completely'. For sample items see Table 1. In the statistical analyses described below we will use the two broad subscales of educational and learning capital respectively.

Self-confidence. Self-confidence was measured with the scale 'Confidence in one's own competence' from Dweck and Henderson (1988), and adapted by Ziegler and Stoeger (2010). This six-point Likert-scale consists of four item pairs with each containing two statements: one pole corresponded to a negative self-evaluation (e.g., "I am not sure that I am good enough to be successful in school.") and one pole corresponded to a positive self-evaluation (e.g., "I am sure that I am good enough to be successful in school.").

Stability beliefs. Stability beliefs were measured with a scale developed by Ziegler and Stoeger (2010). It consists of six items presented as a Likert-type scale, ranging from 1 'I disagree completely' to 6 'I agree completely'. A sample item is "After I have learned something, I don't forget how to apply it." Higher scores on this scale indicate more pronounced stability beliefs.

Modifiability beliefs. Modifiability beliefs were measured with a scale developed by Ziegler and Stoeger (2010). It consists of six items presented as a Likert-type scale, ranging from 1 'I disagree completely' to 6 'I agree completely'. A sample item is "I can improve my skills." Higher scores on this scale indicate more pronounced modifiability beliefs.

Failure coping: Failure coping was assessed with 14 items from a scale developed by Dresel, Schober, Ziegler, Grassinger, and Steuer (2013). It is a six-point Likert-type scale, ranging from 1 'I disagree completely' to 6 'I agree completely'. This scale measures the degree to which a person copes adaptively after failure, such as increasing their effort, for example (e.g., "When I've made a mistake, I aim to improve myself."). Higher scores on this scale indicate a higher degree of failure coping.

\section{Data analysis}

First, we inspected zero-order correlations in order to explore the bivariate relations between each pair of variables. Second, we tested the mediation hypothesis that the effect of 
educational capital is mediated by learning capital within a stepwise regression framework, as proposed by Baron and Kenny (1986). According to the authors, three conditions must be met. First, there must be a relationship between the predictor variable and the dependent variable. Thus, educational capital and learning capital need to predict the outcome variables. Second, the independent variable must affect the mediator, that is, educational capital must predict learning capital. Third, mediation occurs when a previously significant relationship between the independent and the dependent variable is no longer significant when controlling for the effect of the mediator. Partial mediation occurs when the relationship between the predictor and the dependent variable is reduced.

\section{Results}

Table 2 shows the means $(M)$ and standard deviations (SD) of the QELC subscales and of the outcome measures. Table 3 contains the zero-order correlations for all scales. Results show that the predictor variable (educational capital), the mediation variable (learning capital) and the outcome variables are all correlated, fulfilling the first two conditions for the test of a mediation effect. In addition, none of the correlation coefficients for the relation between the variables exceeded .80 , suggesting no problems with multicolinearity (Tabachnick \& Fidell, 2007).

In the next step of the analyses we ran a series of 16 regression analyses according to the suggestions of Baron and Kenny (1986). These results are presented in Table 4. Educational capital predicted all outcome variables significantly. It accounted for $12 \%$ of the variance of self-confidence, $F(1,208)=29.62, p<.001,4 \%$ of the variance of stability beliefs, $F(1,207)=9.63, p<.001,8 \%$ of the variance of modifiability beliefs, $F(1,207)=19.01, p<.001$, an $21 \%$ of the variance of failure coping, $F(1,208)=57.01, p<.001$. In addition, educational capital accounted for $56 \%$ of the variance of learning capital, $F(1,208)=263.38, p<.001$.

Learning capital proved to be even a stronger predictor of the outcome variables. It accounted for $27 \%$ of the variance of self-confidence, $F(1,208)=79.48, p<.001,9 \%$ of the variance of stability beliefs, $F(1,207)=22.30, p<.001,22 \%$ of the variance of modifiability beliefs, $F(1,207)=60.35, p<.001$, and $35 \%$ of the variance of failure coping, $F(1,208)=111.26, p<.001$.

All regression models including educational and learning capital were significant. Adding learning capital as a second predictor variable resulted in every outcome variable having a higher variance explanation than educational capital alone. In the next step we decomposed these significant interactions by calculating simple slopes and intercepts (Peacher, Curran, \& Bauer, 2006). As can be seen in Table 4, educational capital was no longer a significant predictor. According to the logic of a mediation analysis, these findings imply that the effect of educational capital on the four outcome variables is mediated by learning capital.

\section{Summary of main findings of Study 1}

Study 1 had two main aims. First, we wanted to know if a higher possession of educational and learning capital is associated with more favorable expressions of indicators of robustness and resilience. Indeed, all the correlations proved to be significant. The capitals explained between $9 \%$ and $34 \%$ of the variances of the outcome variables. The second aim was to explore whether learning capital mediates the effect of educational capital on robustness and resilience. In line with expectations it was confirmed that educational capital was mediated by learning capital. Overall the results provide substance to the proposed motivational strategy of a learning resource-oriented homeostatic orientation for gifted educators that is focused on providing rich sources of educational and learning capital.

\section{Study 2}

\section{Aims of Study 2}


Whereas Study 1 focused on finding evidence for the motivational basis of a learning resource-oriented homeostatic orientation among gifted educators, Study 2 focused on the empirical basis for a learning resource-oriented allostatic orientation. This was accomplished by showing that the developmental level of an actiotope is dependent on the availability of educational and learning capital and that the effects of educational capital are mediated by learning capital.

The developmental level of an actiotope will be studied on two levels: the component perspective and the dynamic perspective of an actiotope (Ziegler et al., 2013). Ziegler (2005) distinguished four different components of an actiotope that interact with each other: (1) an individual's action repertoire, (2) their goals, (3) their environment, and (4) their subjective action space (for details see Ziegler, 2005). These components are not static but in a dynamic interplay and, with regard to allostatic developments, in a continuous process of co-evolution (Ziegler \& Phillipson, 2012). Ziegler (2005) suggested five dynamic functions, which must be fulfilled for orderly development as opposed to chaotic change. Individuals must be (1) able to assess the correctness of an action, that is, whether it has led to a goal, and (2) the applicability of an action, that is, in what situations an action can be successfully applied. The individual must be further able to construct (3) action variants, thereby expanding their action repertoire. The action repertoire must be (4) anticipative, that is, prepared to cope with new challenges such as learning barriers or learning setbacks. Finally, to facilitate growth, individuals need (5) effective feedback-loops.

\section{Method of Study 2}

\section{Participants}

The sample of Study 2 consisted of 248 students ( 89 male and 159 female) aged from 16 to $20(M=17.83, S D=1.07)$. All participants attended different branches of the same specialized post-secondary business school as the sample of Study 1. They were enrolled in grades 11 to 13. However, as grade level and sex were not systematically related to any of the outcome variables, we again pooled the data.

\section{Materials and procedure}

All 248 participants completed the same materials, which comprised some personal data, the Questionnaire of Educational and Learning Capital (see materials of Study 1) and the Actiotope Questionnaire (Ziegler, 2008; Ziegler, Stoeger, Harder, Park, Portešová, \& Porath, 2014).

Actiotope Questionnaire. Students' actiotopes were assessed with the components and dynamic function subscales of the Actiotope Questionnaire (Ziegler, 2008; Ziegler et al., 2014). This questionnaire provides information on the extent to which students have successfully integrated academic learning in their actiotope. The subscales contained 40 items, 15 items of which tapped the actiotope components and 25 of which tapped the functions. Each subscale consisted of five items answered on a four-point Likert-type scale, ranging from 1 'I disagree completely' to 4 'I agree completely'. Sample items for the actiotope components are: "I know how I can learn successfully for school" (subjective action space); "It is important for me to improve how I study for school" (goals); and "It means a lot to my parents for me to be good in school" (environment, the students' learning environment). Sample items for the dynamic perspective of the actiotope are: "In school I already know whether my answer is going to be right or wrong when I get called on in class and have yet to give my answer" (correctness); "So far I have always been able to figure out whether I can use something in everyday life that I have learned in school" (applicability); "I like trying out new ways of coming to the same result at learning" (action variants); "I always follow a basic rule: It's better to learn too much than too little before a class test" (anticipation); and "I am 
regularly notified from my teachers about what I can already do well and where I need to keep working" (feedback).

Action repertoire. As a measure for the action repertoire we used school achievement. This was operationalized by averaging the grades obtained in the subjects, German (native language), English (first foreign language), and Mathematics on recent report cards. Grades in Germany range from 1 (best possible grade) to 6 (worst possible grade), thus higher scores on this scale indicate that the student exhibits lower school achievements.

Cronbach's $\alpha$ of all scales can be found in Table 5. Unfortunately, some of the reliabilities were rather low, thus making it more difficult to detect significant associations between educational and learning capital and the outcome variables and possible mediations.

\section{Results}

Means $(M)$ and standard deviations (SD) of the QELC subscales, Actiotope subscales, and the action repertoire are shown in Table 5 and correlations in Table 6 . The correlation between educational and learning capital, and all correlations between these two scales and all the outcome variables were statistically significant, thus fulfilling the preconditions for analysing mediation effects. Furthermore, none of the correlation coefficients for the relationships between the variables exceeded .80, suggesting no problems with multicollinearity (Tabachnick \& Fidell, 2007).

In order to test the hypothesis that the effect of educational capital on the outcome variables is mediated by learning capital we again followed the procedure suggested by Baron and Kenny (1986). Therefore, a total of 36 regression analyses were conducted. The results are presented in Table 7.

Educational capital predicted all outcome variables. Explained variances ranged from 1\% (subjective action space) to $17 \%$ (anticipation). Furthermore, educational capital predicted learning capital. Similarly, learning capital predicted all outcome variables. Explained variances ranged between 10\% (subjective action space) and 27\% (anticipation).

All models including educational capital and learning capital as independent variables were significant. As in Study 1 these significant interactions were decomposed by calculating slopes and intercepts (Peacher et al., 2006). Learning capital still remained a significant predictor and accounted for as much variance as when it was the only predictor. However, including educational capital accounted for more variance in some cases. Educational capital still remained a significant predictor for the outcome variables of environment, action variants, and feedback. It remained only a marginally significant $(\mathrm{p}<0.10)$ predictor of the outcome variables of subjective action space and anticipation. However, as explained variances were increased by the inclusion of educational capital, results indicate in these cases a partial mediation by learning capital. In all other regressions educational capital was no longer a significant predictor, thereby indicating mediation.

\section{Summary of main findings of Study 1}

Study 2 had two main aims. First, we wanted to know if the possession of educational and learning capital is associated with more favorable expressions of indicators of growth of an actiotope. Indeed, all the correlations between educational capital, learning capital and the outcome variables proved to be significant. The second aim was to explore whether learning capital mediates the effect of educational capital on the growth indicators of the actiotope. In line with expectations it was confirmed that the effects of educational capital on the subscales of environment, action variants, feedback, action space and anticipation were partially mediated while the effects on the subscales of action repertoire, goals, correctness, and applicability were completely mediated by learning capital. 


\section{Conclusions}

In this work we posited two learning resource-oriented motivational strategies for gifted educators. The first one is a homeostatic orientation, which aims for balance in an actiotope. Its two central sub-goals are robustness and resilience of an actiotope. Two predictions were tested in an empirical study. It could be shown that more exogenous (educational capital) and endogenous learning resources (learning capital) in an actiotope are associated with more robustness and resilience. Furthermore it could be shown that the effect of educational capital on robustness and resilience is mediated by learning capital. Thus, the evidence suggests that a homeostatic orientation adopted by a gifted educator is a valid motivational strategy.

The second learning resource-oriented motivational strategy aims at growth, and is an allostatic development of an actiotope. Again, two predictions were tested in an empirical study. In line with expectations it could be shown that more exogenous and endogenous learning resources in an actiotope are associated with a more developed actiotope with regard to academic learning. In addition it could be shown that the effect of educational capital on a more developed actiotope is partially or completely mediated by learning capital. Thus, the evidence suggests that an allostatic orientation adopted by a gifted educator is also a valid motivational strategy.

Having established the empirical basis for the two motivational strategies we want to highlight the similarity between them and the two opposing positions in an ongoing debate in gifted education (Dai \& Chen, 2013; Subotnik, Olszewski-Kubilius, \& Worrell, 2011; Ziegler, Stoeger, \& Vialle, 2012). The debate concerns whether outstanding achievement or eminence ought to be the chief goal of gifted education (Subotnik et al., 2011) or whether we should focus instead on the needs of the gifted (Feldhusen, 1982). From a learning resource-oriented perspective both orientations make sense, the former reflecting an allostatic orientation and the latter reflecting a homeostatic orientation. While the allostatic orientation focuses on growth and might lead eventually to eminence, the homeostatic educational orientation focuses on balance within the actiotope. Thus, we can rephrase the ongoing debate in gifted education in the language of our own approach: How will the pursuit of the two strategies affect each other or, more specifically, will there be synergies and/or interferences between the two motivational strategies? We will discuss this issue with regard to some characteristics of learning resource-oriented gifted education we have recently suggested (Ziegler, Chandler et al., in press).

Whereas traditional gifted identification has focused on the selection of individuals, a learning resource-oriented approach maintains that the diagnosis of available learning resources should be a crucial part in any identification irrespective of whether a homeostatic or an allostatic orientation is pursued (Ziegler et al., submitted). Thus, with regard to identification one certainly has to expect synergies between the two motivational strategies. Both need to be informed on the resources in an actiotope that can be drawn on in order to pursue educational goals. However, beyond this basic interest in the availability of resources there exist some further aspects of advanced gifted identification for which one might expect synergies: the investigation of the synchronization of the learning resources in an actiotope, and the detection of possible tension zones. Synchronization refers to the degree to which the resources in an actiotope are aligned to attain a certain goal. For example, in one study Ziegler, Stoeger et al. (in press) asked secondary school students several questions concerning the availability of learning resources. Those students who synchronized their learning resources better with regard to school, exhibited much better school achievement. Whereas synchronization of resources refers to a specific point in time, a tension zone is defined as a transitional zone between different points in time that encompass major changes (Barton \& Hewitt, 1985; Ziegler, Chandler et al., in press). A tension zone can either lead to a desired or 
an undesired development. In the former case, the identification would need to address the question of whether all the necessary resources are available for growth. In the latter case, the identification would be concerned with the question of whether all the resources are available in order to prevent possible regression and to keep balance.

From a homeostatic and an allostatic orientation several important principles can be derived. For example, the homeostatic orientation implies the law of the minimum (Salisbury, 1992; Ziegler et al., submitted). It maintains that the stability of an actiotope is not controlled by the total amount of available resources, but by the scarcest resource. This is why a resourceoriented gifted education has to make sure by default that all resources are available and if this is not the case it has to consider remediation. A typical implication of an allostatic orientation is the continuity principle. It states that sufficient exogenous and endogenous learning resources have to be available at every point of time during growth processes. However, though the law of the minimum and the continuity principle were derived from different motivational strategies, they are not limited to their respective motivational strategy but benefit both. For example, the law of the minimum and the continuity principle resemble each other in that they both focus on a possible scarcity of resources either with regard to balance (law of the minimum) or with regard to growth (continuity principle). Thus, they can be seen to complement each other rather than to interfere with each other. The close connection of educational implications following both motivational strategies can also be seen when one considers a further principle, the caution principle, which follows from both the homeostatic and the allostatic orientation (Ziegler et al., submitted). The caution principle is based on the insight that every action also has unanticipated or unintended consequences (Merton, 1936; Mica, Peisert, \& Winczorek, 2011), which have been termed 'iatrogenic effects' and defined as the unintentional detrimental effects on resources precipitated, induced, or exacerbated by gifted education. A well-known example is the fact that being identified and labelled as gifted can have negative consequences (e.g., Freeman, 2006a, 2006b; Heller, 2000, 2004). It is important to note that the caution principle applies to both motivational strategies and is not limited to one of them.

In summing up, we want to emphasize that the two motivational strategies, despite aiming at different goals, are closely related and offer many possibilities for synergies. Thus, in light of the many possible synergies between a homeostatic and an allostatic orientation there seems to be a reasonable third position in the ongoing debate on whether outstanding achievement or eminence ought to be the chief goal of gifted education (Subotnik et al., 2011) or whether we should focus instead on the needs of the gifted (Feldhusen, 1982). While focusing on the proliferation of learning resources, gifted education might simultaneously foster balance and growth in an actiotope.

\section{Limitations}

In general, the current findings confirm the empirical basis of two learning resource-oriented motivational strategies for gifted educators. However, there are two basic limitations that need to be addressed in the future. First, educational and learning capital cannot be measured in their entirety. This sets an upper boundary to possible effect sizes and the validity of the measurements. In our study we used a questionnaire for measurement. Alternative measurements such as teachers' ratings might have led to more valid results and could be useful in future studies. The same considerations apply to the measurement of our outcome variables, in particular in Study 2 where some of the reliabilities were low. However, having established the predicted effects despite the low reliabilities lends some credibility to the two overarching expectations that the availability of learning resources is associated with robustness, resilience, and growth of an actiotope and that the effects of educational capital are mediated by learning capital. A further limitation is that our statistical approach tries to fit 
processes from many occasions into a single model at one time (Edmonds, 2012). As a crucial precondition for such an approach the ergodicity assumption would need to be confirmed (Molenaar, 2008). However, this would require alternative research designs that were not possible with the sample of our study.

\section{References}

Allen, C.R. \& Holling, C.S. (2008). Cross-scale structure and the generation of innovation and novelty in discontinuous complex systems. In C.R. Allen \& C.S. Holling (Eds.), Discontinuities in ecosystems and other complex systems (pp. 219-233). New York: Columbia University Press.

Alomar, B.O. (2003). Parental involvement in the schooling of children. Gifted and Talented International, 18(2), 95-100.

Baron, R.M. \& Kenny, D.A. (1986). The moderator-mediator variable distinction in social psychological research: Conceptual, strategic, and statistical considerations. Journal of Personality and Social Psychology, 51(6), 1173-1182. doi: 10.1037/0022-3514.51.6.1173

Barton, N.H., \& Hewitt, G.M. (1985). Analysis of hybrid zones. Annual Review of Ecology and Systematics, 16, 113-148.

Bellisle, F. (2004). Effects of diet on behavior and cognition in children. British Journal of Nutrition, 92, 227-232. doi: http://dx.doi.org/10.1079/BJN20041171

Bloom, B.S. (Ed.). (1985). Developing talent in young people. New York: Ballantine Books.

Csikszentmihalyi, M., Rathunde, K., \& Whalen, S. (1993). Talented teenagers: The roots of success and failure. Cambridge, UK: Cambridge University Press.

Dai, D.Y. \& Chen, F. (2013). Three paradigms of gifted education: in search of conceptual clarity in research and practice. Gifted Child Quarterly, 57, 151-168.

Dresel, M., Schober, B., Ziegler, A., Grassinger, R., \& Steuer, G. (2013). Affektivmotivational adaptive und handlungsadaptive Reaktionen auf Fehler im Lernprozess. Zeitschrift für Pädagogische Psychologie, 27(4), 255-271. doi: http://dx.doi.org/10.1024/1010-0652/a000111

Dweck, C.S. \& Henderson, V.L. (1988). Theories of intelligence: Background and measures. Champaign-Urbana, University of Illinois. Unpublished manuscript.

Dweck, C.S. (1986). Motivational processes affecting learning. American Psychologist, 41(10), 1040-1048. doi: 10.1037/0003-066X.41.10.1040

Dweck, C.S. (1999). Self-theories: Their role in motivation, personality and development. Philadelphia: Psychology Press.

Dweck, C.S. (2006). Mindset: The new psychology of success. New York: Random House.

Edmonds, B. (2012). Context in social simulation: why it can't be wished away. Computational and Mathematical Organization Theory, 18, 5-21.

Feldhusen, J. (1982). Myth: Gifted education means having a program meeting the needs of gifted students through differentiated programming. Gifted Child Quarterly, 26, 1982, 3741.doi:10.1177/001698628202600113

Ford, M. (1992). Motivating humans: Goals, emotions, and personal agency beliefs. NewBury Park, CA: Sage Publications. 
Freeman, J. (2006a). Emotional problems of the gifted child. Journal of Child Psychology and Psychiatry, 24, 481-485.

Freeman, J. (2006b). Giftedness in the long term. Journal for the Education of the Gifted, 29, 384-403.

Gienger, C., Petermann, F., \& Petermann, U. (2008). Wie stark hängen die HAWIK-IVBefunde vom Bildungsstand der Eltern ab? [How strong is the association of HAWIK-IV results and educational background of the parents?] Kindheit und Entwicklung, 17(2), 90-98. doi: $10.1026 / 0942-5403.17 .2 .90$

Gist, E.M. \& Mitchell, T.R. (1992). Self-efficacy: A theoretical analysis of its determinants and malleability. The Academy of Management Review, 17(2), 183-211. doi: 10.5465/AMR. 1992.4279530

Gottfredson, L.S. (2004). Life, death, and intelligence. Journal of Cognitive Education and Psychology, 4, 23-46.

Gottfried, A. E., \& Gottfried, A. W. (2009). Development of gifted motivation from childhood through young adulthood: Longitudinal research and implications for gifted assessment and education (pp. 617-631). In L. Shavinina (Ed.), International handbook of giftedness and talent. New York, NY: Springer Science.

Gottfried, A. W., Gottfried, A. E., \& Guerin, D. W. (2006). The Fullerton longitudinal study: A longterm investigation of intellectual and motivational giftedness. Journal for the Education of the Gifted, 29(4), 430-450.

Grassinger, R., Porath, M. \& Ziegler, A. (2010). Mentoring: conceptual foundations and effectivity analysis. High Ability Studies, 21, 27-46.

Gunderson, L.H., Folke, C., \& Janssen, M. (2006). Generating and fostering novelty. Ecology and Society 11(1), 50. Retrieval date: 07 June 2016. Retrieved from: http://www.ecologyandsociety.org/vol11/iss1/art50/

Hanushek, E.A. \& Kimko. D.D. (2000). Schooling, labor-force quality, and the growth of nations. The American Economic Review, 90(5), 1184-1208. Retrieved from http://www.jstor.org/stable/2677847

Heller, K. A. (2000). Hochbegabung im Kindes- und Jugendalter [Giftedness in childhood and adolescence]. Goettingen, Germany: Hogrefe Verlag.

Heller, K. A. (2004). Identification of gifted and talented students. Psychology Science, 46, 302-323.

Kitano, H. (2004) Biological robustness. Nature Review Genetics, 5, 826-837.

Leana-Tascilar, M. Z. (2015). The Actiotope Model of Giftedness: Its relationship with motivation, and the prediction of academic achievement among Turkish students. The Australian Educational and Developmental Psychologist, 32, 1-15.

Lipsey, M.W. \& Wilson, D.B. (1993). The efficacy of psychological, educational, and behavioral treatment. American Psychologist, 48, 1181-1201.

Mantzicopoulos, P. (1990). Coping with school failure: Characteristics of students employing successful and unsuccessful coping strategies. Psychology in the Schools, 27(2), 138-143. doi: 10.1002/1520-6807(199004)27:2<138::AID-PITS2310270208>3.0.CO;2-8

Merton, R.K. (1936. The unanticipated consequences of purposive social action. American Sociological

Review,

1,

894-904.

Online: 
http://www.d.umn.edu/cla/faculty/jhamlin/4111/2111-

home/CD/TheoryClass/Readings/MertonSocialAction.pdf . Retrieval date: 7. Juni 2016.

Mica, A. Peisert, A., \& Winczorek J. (Eds.). (2011). Sociology and the unintended. Robert Merton revisited. Frankfurt am Main, Germany: Peter Lang.

Mietzel, G. (2005). Wege in die Psychologie [Ways to psychology](12. ed.). Stuttgart, Germany: Klett-Cotta.

Molenaar, P.C.M. (2008). Consequences of the ergodic theorems for classic test theory, factor analysis, and the analysis of developmental process. In S.M. Hofer \& D.F. Alwin (Eds.), Handbook of cognitive aging (pp. 90-104). Thousand Oaks, CA: Sage, 90-104.

Newton, T.J. \& Keenan, A. (1985). Coping with work-related stress. Human Relations, 38(2), 107-126. doi: $10.1177 / 001872678503800202$

OECD (2010). PISA 2009 Ergebnisse: Zusammenfassung [PISA 2009 results: Summary]. Retrieved from http://www.oecd.org/pisa/pisaproducts/46619755.pdf

Pajares, F. (1996). Self-efficacy beliefs in academic settings. Review of Educational Research, 66(4), 543-578. doi:10.3102/00346543066004543

Phillipson. S., Stoeger. H., \& Ziegler. A. (Eds.) (2013). Development of excellence in EastAsia: Explorations in the Actiotope model of giftedness. London: Routledge.

Preacher, K.J., Curran, P.J., \& Bauer, D.J. (2006). Computational tools for probing interaction effects in multiple linear regression, multilevel modeling, and latent curve analysis. Journal of Educational and Behavioral Statistics, 31(4), 437-448. doi: 10.3102/10769986031004437

Salisbury, F. (1992) Plant physiology (4 ${ }^{\text {th }}$ edition). Belmont, CA: Wadsworth, CA.

Schunk, D. H., Pintrich, P. R., \& Meece, M. L. (2008) Motivation in education: Theory, research, and applications (3rd ed.). Upper Saddle River, NJ: Pearson.

Shavinina, L. (Ed.) (2009). International handbook of giftedness and talent. New York, NY: Springer Science.

Siegle, D., \& McCoach, D. B. (2005). Motivating gifted students. Waco, TX: Prufrock Press

Subotnik, R.F., Olszewski-Kubilius, P., \& Worrell, F.C. (2011). Rethinking giftedness and gifted education: A proposed direction forward based on psychological science. Psychological Science in the Public Interest, 12, 3-54.

Tabachnick, B.G., \& Fidell, L.S. (2007). Using multivariate statistics. Boston: Pearson.

Veas, A., Castejón, J.-L., O’Reilly, C., \& Ziegler, A. (2016). Mediation analysis of the relationship between educational capital, learning capital and underachievement among gifted secondary school students. Journal for the Education of the Gifted, 39.

Vladut, A., Liu, Q., Leana-Tascila, M.Z., Vialle, W., \& Ziegler, A. (2013). A Cross-Cultural Validation Study of the Questionnaire of Educational and Learning Capital (QELC) in China, Germany and Turkey. Psychological Test and Assessment Modelling, 55(4), 462-478.

Vladut, A., Vialle, W., \& Ziegler, A. (2015). Learning Resources within the Actiotope: A validation study of the QELC (Questionnaire of Educational and Learning Capital). Psychological Test and Assessment Modeling, 57(1), 40-56.

Ziegler, A. (2005). The actiotope model of giftedness. In R.J. Sternberg \& J.E. Davidson (Eds.), Conceptions of giftedness (pp. 411-434). New York: Cambridge University Press.

Ziegler, A. (2008). Fragebogen zur Erfassung des schulischen Aktiotops [Questionnaire to assess the school-based actiotope]. Ulm: University of Ulm. Unpublished manuscript. 
Ziegler, A. \& Baker, J. (2013). Talent development as adaptation: The role of educational and learning capital. In S. Phillipson, H. Stoeger, \& A. Ziegler (Eds.), Exceptionality in East Asia: Explorations in the Actiotope model of giftedness (pp. 18-39). London: Routledge.

Ziegler, A. \& Phillipson, S. (2012). Towards a systemic theory of giftedness. High Ability Studies, 23, 3-30.

Ziegler, A., Chandler, K., Vialle, W., \& Stoeger, H. (2016). Exogenous and endogenous learning resources in the Actiotope Model of Giftedness and its significance for gifted education. Journal for the Education of the Gifted, 39.

Ziegler, A., Debatin, T., \& Stoeger, H. (submitted). Learning resources and talent development from a systemic point of view.

Ziegler, A., Fidelmann, M., Reutlinger, M., Vialle, W., \& Stoeger, H. (2010). Implicit personality theories on the modifiability and stability of the action repertoire as a meaningful framework for individual motivation: a cross-cultural study. High Ability Studies, 21(2), 147163. doi: $10.1080 / 13598139.2010 .528924$

Ziegler, A. \& Stoeger, H. (2010). Research on a modified framework of implicit personality theories. Learning and Individual Differences, 20(4), 318-326. doi:10.1016/j.lindif.2010.01.007

Ziegler, A., Stoeger, H., \& Balestrini, D. (in press). Systemic gifted education. In C. O'Reilly, T. Cross, \& J. Riedl Cross (Eds.), Provisions for gifted students. Dublin: CTYI Press.

Ziegler, A., Stoeger, H., Harder, B., Park, K., Portešová, S., \& Porath, M. (2014). Gender differences in mathematics and science: The role of the actiotope in determining individuals' achievements and confidence in their own abilities. High Ability Studies, 25(1), 35-51. doi: http://dx.doi.org/10.1080/13598139.2014.916092

Ziegler, A. Stoeger, H. \& Vialle, W. (2012). Giftedness and gifted education: The need for a paradigm change. Gifted Child Quarterly, 46, 194-197.

Ziegler, A., Vialle, W., \& Wimmer, B. (2013). The Actiotope model of giftedness: An introduction to some central theoretical assumptions. In S. Phillipson, H. Stoeger, \& A. Ziegler (Eds.), Exceptionality in East Asia: Explorations in the Actiotope model of giftedness (pp. 1-17). London: Routledge. 
Table 1. Definitions and illustrations of the five forms of educational capital and the five forms of learning capital.

\begin{tabular}{lcc}
\hline Type of capital & Definition & Sample item from the \\
& QELC (Vladut et al., \\
& & $2013)$. \\
\hline
\end{tabular}

Educational capital

\begin{tabular}{|c|c|c|c|}
\hline $\begin{array}{l}\text { Economic } \\
\text { educational } \\
\text { capital }\end{array}$ & $\begin{array}{l}\text { Economic educational capital is } \\
\text { every kind of wealth, possession, } \\
\text { money or valuables that can be } \\
\text { invested in the initiation and } \\
\text { maintenance of educational and } \\
\text { learning processes. (p. } 27 \text { ) }\end{array}$ & $\begin{array}{l}\text { The socio-economic status of a family } \\
\text { strongly correlates with the academic } \\
\text { performance of their children (Gienger, } \\
\text { Petermann, \& Petermann, 2008; } \\
\text { Hanushek \& Kimko, 2000; OECD, } \\
\text { 2010). }\end{array}$ & $\begin{array}{l}\text { My family is willing to } \\
\text { spend more money than } \\
\text { others for learning. }\end{array}$ \\
\hline $\begin{array}{l}\text { Cultural } \\
\text { educational } \\
\text { capital }\end{array}$ & $\begin{array}{l}\text { Cultural educational capital includes } \\
\text { value systems, thinking patterns, } \\
\text { models and the like, which can } \\
\text { facilitate - or hinder - the attainment } \\
\text { of learning and educational goals. (p. } \\
\text { 27) }\end{array}$ & $\begin{array}{l}\text { In East Asian countries education and } \\
\text { learning are currently more highly } \\
\text { valued than in Western countries. } \\
\text { Students' achievements benefit from } \\
\text { this (Phillipson, Stoeger, \& Ziegler, } \\
2013 \text { ). }\end{array}$ & $\begin{array}{l}\text { In my social environment } \\
\text { learning is considered to } \\
\text { be very important. }\end{array}$ \\
\hline $\begin{array}{l}\text { Social } \\
\text { educational } \\
\text { capital }\end{array}$ & $\begin{array}{l}\text { Social educational capital includes } \\
\text { all persons and social institutions } \\
\text { that can directly or indirectly } \\
\text { contribute to the success of learning } \\
\text { and educational processes. (p. 28) }\end{array}$ & $\begin{array}{l}\text { Several studies show that parents' } \\
\text { interest and participation in their } \\
\text { children's learning process } \\
\text { significantly contributes to } \\
\text { achievement in that field (Alomar, } \\
\text { 2003; Bloom, 1985; Veas, Castejón, } \\
\text { O'Reilly, \& Ziegler, in press). }\end{array}$ & $\begin{array}{l}\text { My friends and my family } \\
\text { support me in my } \\
\text { learning. }\end{array}$ \\
\hline
\end{tabular}


Infrastructural Infrastructural educational capital educational capital relates to materially implemented possibilities for action that permit learning and education to take place. (p. 28)
This type of capital encompasses

possession of educational toys at home, resource rooms at schools, libraries in a

city. Research shows, for example, that an Olympic career in swimming won't be possible, if the appropriate

infrastructure isn't available from the beginning (Bloom, 1985).

\begin{tabular}{ll}
\hline Didactic & Didactic educational capital means \\
educational & the assembled expertise involved in \\
capital & the design and improvement of \\
& $\begin{array}{l}\text { educational and learning processes. } \\
\text { (p. 29) }\end{array}$
\end{tabular}

An important reason for the increase in average school education effectiveness during the last 120 years is the accumulation of superior didactic know-how. Training based on this know-how can produce enhanced effect sizes of at least half a standard deviation (e.g. Lipsey \& Wilson, 1993). educational and learning proc (p.

1993).
I have optimal learning opportunities.

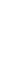

I use suggestions and tips on how I learn best.

\section{Learning capital}

\begin{tabular}{llll}
\hline $\begin{array}{l}\text { Organismic } \\
\text { learning } \\
\text { capital }\end{array}$ & $\begin{array}{l}\text { Organismic learning capital consists } \\
\text { of the physiological and } \\
\text { constitutional resources of a person. } \\
\text { (p. 29) }\end{array}$ & $\begin{array}{l}\text { Physical fitness is an important } \\
\text { precondition not only for athletic } \\
\text { performance, but also for higher } \\
\text { cognitive achievements (Bellisle, 2004; } \\
\text { Gottfredson, 2004). }\end{array}$ & $\begin{array}{l}\text { My very good physical } \\
\text { condition is a good basis } \\
\text { for my continuous }\end{array}$ \\
\hline $\begin{array}{l}\text { Actional } \\
\text { learning } \\
\text { capital }\end{array}$ & $\begin{array}{l}\text { Actional learning capital means the } \\
\text { action repertoire of a person - the } \\
\text { totality of actions they are capable of } \\
\text { performing. (p. 30) }\end{array}$ & $\begin{array}{l}\text { Elementary school students gradually } \\
\text { and systematically extend their action }\end{array}$ & $\begin{array}{l}\text { I always know exactly } \\
\text { repertoire in mathematics when } \\
\text { successively learning arithmetic } \\
\text { operations. }\end{array}$ \\
\hline
\end{tabular}




\begin{tabular}{|c|c|c|c|}
\hline $\begin{array}{l}\text { Telic } \\
\text { learning } \\
\text { capital }\end{array}$ & $\begin{array}{l}\text { Telic learning capital comprises the } \\
\text { totality of a person's anticipated goal } \\
\text { states that offer possibilities for } \\
\text { satisfying their needs. (p. } 30 \text { ) }\end{array}$ & $\begin{array}{l}\text { Learning-orientated students choose } \\
\text { challenging tasks and therefore can } \\
\text { reach higher learning goals (Dweck, } \\
\text { 1986). }\end{array}$ & $\begin{array}{l}\text { I have set myself the } \\
\text { learning goal to learn } \\
\text { more and more. }\end{array}$ \\
\hline $\begin{array}{l}\text { Episodic } \\
\text { learning } \\
\text { capital }\end{array}$ & $\begin{array}{l}\text { Episodic learning capital concerns } \\
\text { the simultaneous goal- and situation- } \\
\text { relevant action patterns that are } \\
\text { accessible to a person. (p. } 31 \text { ) }\end{array}$ & $\begin{array}{l}\text { Students who fluently speak a foreign } \\
\text { language are theoretically able to } \\
\text { express anything in this language. But } \\
\text { this does not imply that they will say } \\
\text { the right thing at the right time in the } \\
\text { right situation in any particular } \\
\text { conversation. }\end{array}$ & $\begin{array}{l}\text { Due to various } \\
\text { experiences, I know how I } \\
\text { can achieve outstanding } \\
\text { success. }\end{array}$ \\
\hline $\begin{array}{l}\text { Attentional } \\
\text { learning } \\
\text { capital }\end{array}$ & $\begin{array}{l}\text { Attentional learning capital denotes } \\
\text { the quantitative and qualitative } \\
\text { attentional resources that a person } \\
\text { can apply to learning. (p. } 31 \text { ) }\end{array}$ & $\begin{array}{l}\text { From a quantitative point of view } \\
\text { leisure activities (e.g. watching } \\
\text { television) can reduce the students' } \\
\text { available learning time, while anxious } \\
\text { states can reduce the attentional quality } \\
\text { while learning. }\end{array}$ & $\begin{array}{l}\text { I can concentrate without } \\
\text { distractions on my } \\
\text { learning for school. }\end{array}$ \\
\hline
\end{tabular}

Note: All definitions are quotes from Ziegler \& Baker (2013). 
Table 2. Means $(M)$, standard deviations (SD, and reliabilities (Cronbach's $\alpha$ ) of the scales in Study 1.

\begin{tabular}{lcc}
\hline Scale & $M(S D)$ & Reliability \\
\hline Educational capital & $3.93(0.65)$ & .81 \\
Learning capital & $4.03(0.69)$ & .89 \\
Self-confidence & $4.32(0.87)$ & .77 \\
Stability beliefs & $3.71(0.90)$ & .84 \\
Modifiability beliefs & $4.59(0.71)$ & .72 \\
Failure coping & $4.14(0.65)$ & .83 \\
\hline
\end{tabular}


Table 3. Zero-order correlations of all subscales in Study 1.

\begin{tabular}{|c|c|c|c|c|c|}
\hline & 2 & 3 & 4 & 5 & 6 \\
\hline 1 Educational capital & $.748^{* *}$ & $.354 * *$ & $.465^{* *}$ & $.211 * *$ & $.291 * *$ \\
\hline 2 Learning capital & & $.527 * *$ & $.591 * *$ & $.313 * *$ & $.476 * *$ \\
\hline 3 Confidence & & & $.352 * *$ & $.245 * *$ & $.337 * *$ \\
\hline 4 Failure coping & & & & $.210 * *$ & $.499 * *$ \\
\hline 5 Stability belief & & & & & $.236 * *$ \\
\hline 6 Modifiability beliefs. & & & & & - \\
\hline
\end{tabular}


Table 4. Results of the regression analyses in Study 1.

\begin{tabular}{|c|c|c|c|c|c|c|c|c|c|}
\hline Model & $\begin{array}{l}\text { Dependent } \\
\text { variable }\end{array}$ & Independent variable & $B$ & $S E$ & $\beta$ & $p$ & $\begin{array}{c}\text { Corrected } \\
R^{2}\end{array}$ & $F$ & $p$ \\
\hline & Confidence & Educational capital & .47 & .09 & .35 & .00 & .12 & 29.62 & .00 \\
\hline 2 & Confidence & Learning capital & .66 & .08 & .53 & .00 & .27 & 79.48 & .00 \\
\hline 3 & Learning capital & Educational capital & .79 & .05 & .75 & .00 & .56 & 263.38 & .00 \\
\hline \multirow[t]{2}{*}{4} & Confidence & Educational capital & -.12 & .12 & -.09 & .30 & .27 & & \\
\hline & & Learning capital & .75 & .11 & .60 & .00 & .27 & 40.28 & .00 \\
\hline Model & $\begin{array}{l}\text { Dependent } \\
\text { variable }\end{array}$ & Independent variable & $B$ & $S E$ & $\beta$ & $p$ & $\begin{array}{c}\text { Corrected } \\
R^{2}\end{array}$ & $F$ & $p$ \\
\hline 1 & Stability belief & Educational capital & .29 & .09 & .21 & .00 & .04 & 9.63 & .00 \\
\hline 2 & Stability belief & Learning capital & .41 & .09 & .31 & .00 & .09 & 22.30 & .00 \\
\hline 3 & Learning capital & Educational capital & .79 & .05 & .75 & .00 & .56 & 263.38 & .00 \\
\hline \multirow[t]{2}{*}{4} & Stability belief & Educational capital & -.07 & .14 & -.05 & .60 & .09 & & \\
\hline & & Learning capital & .46 & .13 & .35 & .00 & .09 & 11.25 & .00 \\
\hline Model & $\begin{array}{l}\text { Dependent } \\
\text { variable }\end{array}$ & Independent variable & $B$ & $S E$ & $\beta$ & $p$ & $\begin{array}{c}\text { Corrected } \\
R^{2}\end{array}$ & $F$ & $p$ \\
\hline 1 & $\begin{array}{l}\text { Modifiability } \\
\text { belief }\end{array}$ & Educational capital & .31 & .07 & .29 & .00 & .08 & 19.01 & .00 \\
\hline 2 & $\begin{array}{l}\text { Modifiability } \\
\text { belief }\end{array}$ & Learning capital & .49 & .06 & .48 & .00 & .22 & 60.35 & .00 \\
\hline 3 & Learning capital & Educational capital & .79 & .05 & .75 & .00 & .56 & 263.38 & .00 \\
\hline 4 & $\begin{array}{l}\text { Modifiability } \\
\text { belief }\end{array}$ & Educational capital & -.16 & .10 & -.15 & .10 & .23 & & \\
\hline
\end{tabular}




\begin{tabular}{cccccccccc} 
& \multicolumn{1}{c}{$\begin{array}{c}\text { Learning } \\
\text { capital }\end{array}$} & .60 & .09 & .59 & .00 & .23 & 31.76 & .00 \\
\hline Model & $\begin{array}{c}\text { Dependent } \\
\text { variable }\end{array}$ & Independent variable & $B$ & $S E$ & $\beta$ & $p$ & $\begin{array}{c}\text { Corrected } \\
R^{2}\end{array}$ & $F$ \\
\hline 1 & Failure coping & Educational capital & .46 & .06 & .47 & .00 & .21 & 57.01 & .00 \\
\hline 2 & Failure coping & Learning capital & .56 & .05 & .59 & .00 & .35 & 111.26 & .00 \\
\hline 3 & Learning capital & Educational capital & .79 & .05 & .75 & .00 & .56 & 263.38 \\
\hline 4 & Failure coping & Educational capital & .05 & .08 & .05 & .55 & .34 & .00 \\
& & Learning capital & .52 & .08 & .55 & .00 & .34 & 55.64 \\
\hline
\end{tabular}


Table 5. Means $(M)$, standard deviations ( $S D$, and reliabilities (Cronbach's $\alpha$ ) of the scales in Study 2.

\begin{tabular}{lcc}
\hline Scale & $N=248$ & Reliability \\
& $M(S D)$ & \\
\hline Educational capital & $3.80(0.58)$ & .72 \\
Learning capital & $3.99(0.69)$ & .89 \\
Action repertoire & $2.70(0.59)$ & .46 \\
Goals & $2.77(0.44)$ & .47 \\
Environment & $2.76(0.40)$ & .30 \\
Correctness & $2.70(0.47)$ & .59 \\
Applicability & $2.49(0.47)$ & .55 \\
Action variants & $2.29(0.51)$ & .69 \\
Anticipation & $2.43(0.51)$ & .61 \\
Feedback & $2.09(0.58)$ & .75 \\
\hline
\end{tabular}


Table 6. Zero-order correlations of all subscales in Study 2.

\begin{tabular}{|c|c|c|c|c|c|c|c|c|c|c|c|}
\hline & & 2 & 3 & 4 & 5 & 6 & 7 & 8 & 9 & 10 & 11 \\
\hline 1 & Educational capital & $.651^{* *}$ & $-.241^{* *}$ & $.337^{* *}$ & $.386^{* *}$ & $.130^{*}$ & $.263^{* *}$ & $.225^{* *}$ & $.397^{* *}$ & $.411^{* *}$ & $.348^{* *}$ \\
\hline 2 & Learning capital & & $-.395^{* *}$ & $.435^{* *}$ & $.348^{* *}$ & $.323^{* *}$ & $.455^{* *}$ & $.381^{* *}$ & $.461^{* *}$ & $.523^{* *}$ & $.364^{* *}$ \\
\hline 3 & Action repertoire & & & -.066 & -.079 & $-.417^{* *}$ & $-.259^{* *}$ & $-.251^{* *}$ & -.074 & $-.183^{* *}$ & -.057 \\
\hline 4 & Goals & & & & $.314^{* *}$ & .089 & $.163^{*}$ & $.134^{*}$ & $.311^{* *}$ & $.415^{* *}$ & $.128^{*}$ \\
\hline 5 & Environment & & & & & .063 & $.326^{* *}$ & .110 & $.289^{* *}$ & $.377^{* *}$ & $.290^{* *}$ \\
\hline 6 & Subjective action space & & & & & & $.315^{* *}$ & $.476^{* *}$ & .058 & .070 & .076 \\
\hline 7 & Correctness & & & & & & & $.329^{* *}$ & $.279^{* *}$ & $.359^{* *}$ & $.351^{* *}$ \\
\hline 8 & Applicability & & & & & & & & $.270^{* *}$ & $.229^{* *}$ & $.227^{* *}$ \\
\hline 9 & Action variants & & & & & & & & & $.438^{* *}$ & $.393^{* *}$ \\
\hline 10 & Anticipation & & & & & & & & & & $.320^{* *}$ \\
\hline 11 & Feedback & & & & & & & & & & \\
\hline
\end{tabular}

Notes: $* \mathrm{p}<.05 ; * * \mathrm{p}<.01$.

Action repertoire is inversely scaled. 
Table 7. Results of the regression analyses in Study 2.

\begin{tabular}{|c|c|c|c|c|c|c|c|c|c|}
\hline Model & Dependent variable & $\begin{array}{l}\text { Independent } \\
\text { variable }\end{array}$ & $B$ & $S E$ & $\beta$ & $p$ & Corrected $R^{2}$ & $F$ & $p$ \\
\hline 1 & Action repertoire & Educational capital & -.22 & .07 & -.21 & .00 & .04 & 11.25 & .00 \\
\hline 2 & Achievement & Learning capital & -.29 & .05 & -.34 & .00 & .11 & 30.94 & .00 \\
\hline 3 & Learning capital & Educational capital & .77 & .06 & .65 & .00 & .42 & 180.54 & .00 \\
\hline \multirow[t]{2}{*}{4} & Achievement & Educational capital & .01 & .08 & .01 & .91 & .11 & & \\
\hline & & Learning capital & -.30 & .07 & -.35 & .00 & .11 & 15.41 & .00 \\
\hline Model & Dependent variable & $\begin{array}{l}\text { Independent } \\
\text { variable }\end{array}$ & $B$ & $S E$ & $\beta$ & $p$ & Corrected $R^{2}$ & $F$ & $p$ \\
\hline 1 & Goals & Educational capital & .26 & .05 & .34 & .00 & .11 & 31.44 & .00 \\
\hline 2 & Goals & Learning capital & .28 & .04 & .44 & .00 & .19 & 57.03 & .00 \\
\hline 3 & Learning capital & Educational capital & .77 & .06 & .65 & .00 & .42 & 180.54 & .00 \\
\hline \multirow[t]{2}{*}{4} & Goals & Educational capital & .07 & .06 & .10 & .21 & .19 & & \\
\hline & & Learning capital & .24 & .05 & .37 & .00 & .19 & 29.39 & .00 \\
\hline Model & Dependent variable & $\begin{array}{l}\text { Independent } \\
\text { variable }\end{array}$ & $B$ & $S E$ & $\beta$ & $p$ & Corrected $R^{2}$ & $F$ & $p$ \\
\hline 1 & Environment & Educational capital & .27 & .04 & .39 & .00 & .15 & 42.80 & .00 \\
\hline 2 & Environment & Learning capital & .20 & .04 & .35 & .00 & .12 & 33.75 & .00 \\
\hline 3 & Learning capital & Educational capital & .77 & .06 & .65 & .00 & .42 & 180.54 & .00 \\
\hline \multirow[t]{2}{*}{4} & Environment & Educational capital & .19 & .05 & .28 & .00 & .16 & & \\
\hline & & Learning capital & .10 & .05 & .17 & .03 & .16 & 24.15 & .00 \\
\hline
\end{tabular}




\begin{tabular}{|c|c|c|c|c|c|c|c|c|c|}
\hline Model & Dependent variable & $\begin{array}{l}\text { Independent } \\
\text { variable }\end{array}$ & B & $\mathrm{SE}$ & $\beta$ & $\mathrm{p}$ & Corrected $\mathrm{R}^{2}$ & $\mathrm{~F}$ & $\mathrm{p}$ \\
\hline 1 & Subjective action space & Educational capital & .11 & .05 & .13 & .04 & .01 & 4.21 & .04 \\
\hline 2 & Subjective action space & Learning capital & .23 & .04 & .32 & .00 & .10 & 28.54 & .00 \\
\hline 3 & Learning capital & Educational capital & .77 & .06 & .65 & .00 & .42 & 180.54 & .00 \\
\hline \multirow[t]{2}{*}{4} & Subjective action space & Educational capital & -.12 & .07 & -.14 & .08 & .11 & & \\
\hline & & Learning capital & .29 & .06 & .41 & .00 & .11 & 15.89 & .00 \\
\hline Model & Dependent variable & $\begin{array}{l}\text { Independent } \\
\text { variable }\end{array}$ & $B$ & $S E$ & $\beta$ & $p$ & Corrected $R^{2}$ & $F$ & $p$ \\
\hline 1 & Correctness & Educational capital & .22 & .05 & .26 & .00 & .07 & 18.28 & .00 \\
\hline 2 & Correctness & Learning capital & .31 & .04 & .46 & .00 & .20 & 64.03 & .00 \\
\hline 3 & Learning capital & Educational capital & .77 & .06 & .65 & .00 & .42 & 180.54 & .00 \\
\hline \multirow[t]{2}{*}{4} & Correctness & Educational capital & -.05 & .06 & -.06 & .46 & .20 & & \\
\hline & & Learning capital & .34 & .05 & .49 & .00 & .20 & 32.22 & .00 \\
\hline Model & Dependent variable & $\begin{array}{l}\text { Independent } \\
\text { variable }\end{array}$ & $B$ & $S E$ & $\beta$ & $p$ & Corrected $R^{2}$ & $F$ & $p$ \\
\hline 1 & Applicability & Educational capital & .18 & .05 & .23 & .00 & .05 & 13.03 & .00 \\
\hline 2 & Applicability & Learning capital & .26 & .04 & .38 & .00 & .14 & 41.60 & .00 \\
\hline 3 & Learning capital & Educational capital & .77 & .06 & .65 & .00 & .42 & 180.54 & .00 \\
\hline \multirow[t]{2}{*}{4} & Applicability & Educational capital & -.03 & .06 & -.04 & .62 & .14 & & \\
\hline & & Learning capital & .28 & .05 & .41 & .00 & .14 & 20.86 & .00 \\
\hline Model & Dependent variable & $\begin{array}{l}\text { Independent } \\
\text { variable }\end{array}$ & $B$ & $S E$ & $\beta$ & $p$ & Corrected $R^{2}$ & $F$ & $p$ \\
\hline
\end{tabular}




\begin{tabular}{|c|c|c|c|c|c|c|c|c|c|}
\hline 1 & Action variants & Educational capital & .35 & .05 & .40 & .00 & .15 & 45.83 & .00 \\
\hline 2 & Action variants & Learning capital & .34 & .04 & .46 & .00 & .21 & 65.97 & .00 \\
\hline 3 & Learning capital & Educational capital & .77 & .06 & .65 & .00 & .42 & 180.54 & .00 \\
\hline \multirow[t]{2}{*}{4} & Action variants & Educational capital & .15 & .07 & .17 & .02 & .22 & & \\
\hline & & Learning capital & .26 & .06 & .35 & .00 & .22 & 36.20 & .00 \\
\hline Model & Dependent variable & $\begin{array}{l}\text { Independent } \\
\text { variable }\end{array}$ & $B$ & $S E$ & $\beta$ & $p$ & Corrected $R^{2}$ & $F$ & $p$ \\
\hline 1 & Anticipation & Educational capital & .37 & .05 & .41 & .00 & .17 & 49.85 & .00 \\
\hline 2 & Anticipation & Learning capital & .39 & .04 & .52 & .00 & .27 & 92.49 & .00 \\
\hline 3 & Learning capital & Educational capital & .77 & .06 & .65 & .00 & .42 & 180.54 & .00 \\
\hline \multirow[t]{2}{*}{4} & Anticipation & Educational capital & .11 & .06 & .12 & .08 & .28 & & \\
\hline & & Learning capital & .33 & .05 & .44 & .00 & .28 & 48.13 & .00 \\
\hline Model & Dependent variable & $\begin{array}{l}\text { Independent } \\
\text { variable }\end{array}$ & $B$ & $S E$ & $\beta$ & $p$ & Corrected $R^{2}$ & $F$ & $p$ \\
\hline 1 & Feedback & Educational capital & .35 & .06 & .35 & .00 & .12 & 33.73 & .00 \\
\hline 2 & Feedback & Learning capital & .31 & .05 & .36 & .00 & .13 & 37.35 & .00 \\
\hline 3 & Learning capital & Educational capital & .77 & .06 & .65 & .00 & .42 & 180.54 & .00 \\
\hline \multirow[t]{2}{*}{4} & Feedback & Educational capital & .19 & .08 & .19 & .01 & .15 & & \\
\hline & & Learning capital & .20 & .07 & .24 & .00 & .15 & 22.19 & .00 \\
\hline
\end{tabular}


Figure 1

\section{Actiotope's environment}

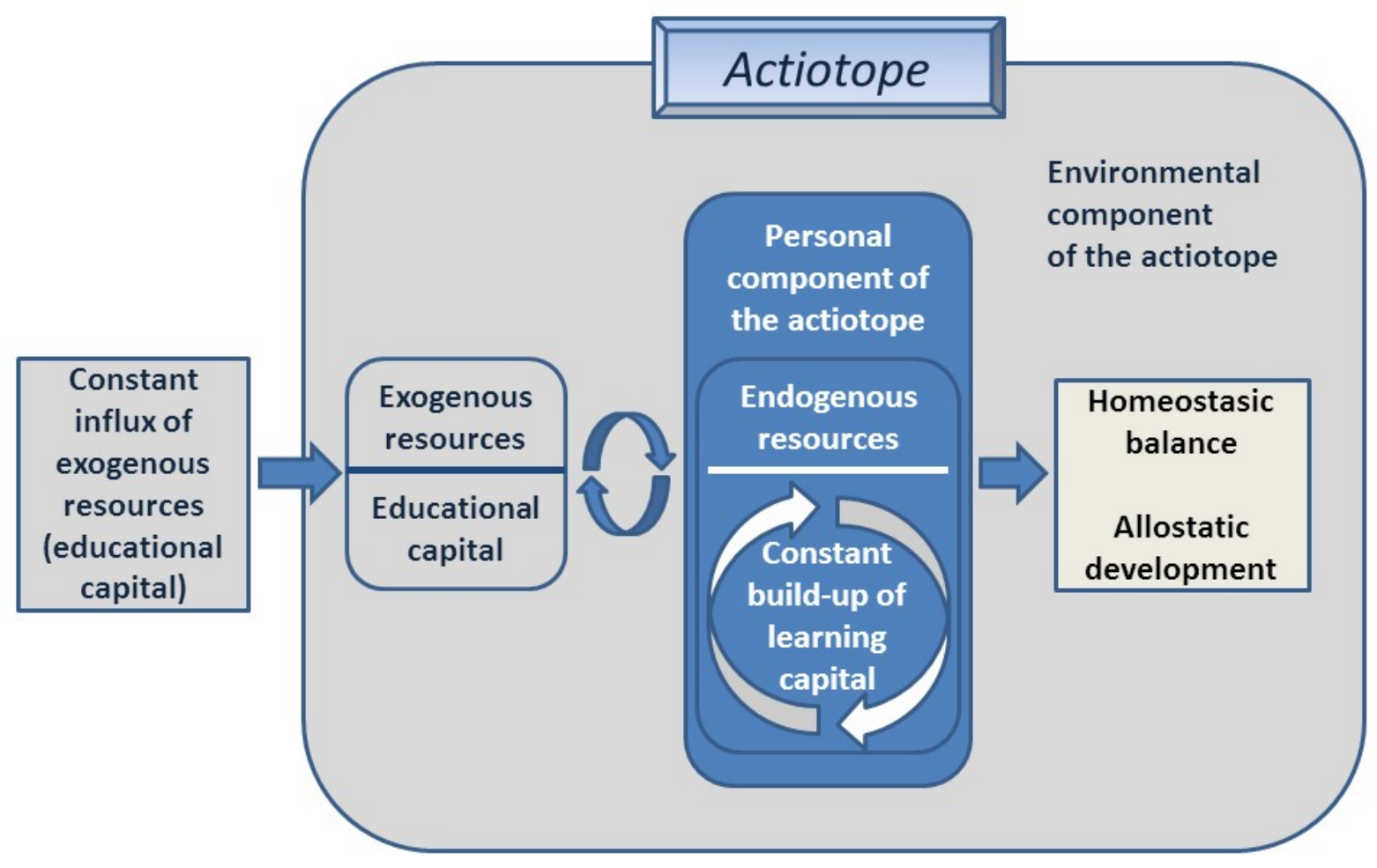

Figure 1: Homeostatic balance and allostatic development as a function of exogenous and endogenous resources in the Actiotope Model of Giftedness. 